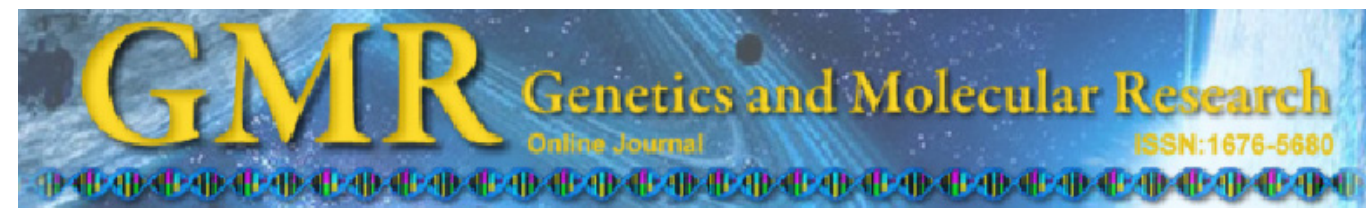

$\underline{\text { Short Communication }}$

\title{
Seventeen polymorphic microsatellite markers developed for the Javelin goby, Synechogobius hasta (Gobiidae)
}

\author{
C.-C. Bai ${ }^{1,2}$, S.-F. Liu' ${ }^{1}$, Z.-M. Zhuang1, Y.-J. Yuan ${ }^{1,3}$, H.-B. Liu ${ }^{1,2}$ and F.-Q. Dai ${ }^{1}$ \\ ${ }^{1}$ Key Laboratory for Fishery Resources and Eco-Environment, \\ Yellow Sea Fisheries Research Institute, \\ Chinese Academy of Fishery Sciences, Qingdao, China \\ ${ }^{2}$ Key Laboratory of Mariculture, Ministry of Agriculture, \\ Dalian Ocean University, Dalian, China \\ ${ }^{3}$ Shanghai Ocean University, Shanghai, China \\ Corresponding author: S.-F. Liu \\ E-mail: liusf@ysfri.ac.cn
}

Genet. Mol. Res. 11 (2): 1465-1468 (2012)

Received November 11, 2011

Accepted March 6, 2012

Published May 18, 2012

DOI http://dx.doi.org/10.4238/2012.May.18.7

\begin{abstract}
Synechogobius hasta is an important commercial marine fish with distinctive features of rapid growth and short lifespan. We isolated and characterized 17 microsatellite markers for $S$. hasta using a (GT) $)_{13}$-enriched genomic library. Polymorphism was assessed in 48 individuals from a single population collected from the northern coastal waters of the Yellow Sea. The number of alleles per locus ranged from 2 to 23 , with a mean of 11.3. The observed and expected heterozygosities ranged from 0.130 to 1.000 and from 0.123 to 0.939 , with means of 0.758 and 0.774 , respectively. Fourteen of 17 loci conformed to Hardy-Weinberg equilibrium and no significant linkage disequilibrium between locus pairs was detected. These microsatellite markers will be useful for population genetic structure analyses.
\end{abstract}

Key words: Javelin goby; Synechogobius hasta; Microsatellite loci; Genetic structure 


\section{INTRODUCTION}

Javelin goby (Synechogobius hasta), which belongs to the family Gobiidae, is a warm-temperature, demersal, euryhaline, amphidromous, commercial fish inhabiting the inshore waters of the northwestern Pacific Ocean from Japan and China to Indonesia (Chen, 1978). Individuals grow rapidly and have a lifespan of just 1 year (Chen, 1978). With the decline in fishery resources in recent years, increasing attention has been paid to $S$. hasta breeding because the fish has good taste and fast growth (Feng et al., 2004; Luo et al., 2008). Most studies on S. hasta have focused mainly on morphology and genetics (Sun and Chen, 1993; Wang and Zhao, 1994; Feng et al., 2010). However, assessments of genetic diversity are also important for conservation and management of this species, because it has high economic and scientific value. Microsatellite markers are highly polymorphic and widely used in genome mapping and population genetic studies in artificially cultured species (Litt and Luty, 1989; Shao et al., 2009; Yang et al., 2010). However, specific microsatellite markers for S. hasta are currently unavailable. Our aim was to isolate and characterize polymorphic microsatellite loci in $S$. hasta to provide useful markers for conservation and management studies of the species.

\section{MATERIAL AND METHODS}

Forty-eight samples of $S$. hasta were collected from the northern coastal waters of the Yellow Sea and preserved in alcohol until DNA extraction. A dinucleotide-enriched genomic library was constructed following the method of Ma and Chen (2009). Genomic DNA was extracted from muscle tissue using the phenol-chloroform procedure (Sambrook and Russell, 2001). Genomic DNA was then digested with MseI restriction enzyme (New England Biolabs, USA). The fragments were ligated to the adapters (5'-TACTCAGGACTCAT-3'/ 5'-GACGATGAGTCCTGAG-3'). Linker-ligated DNA was pre-amplified in $25-\mu \mathrm{L}$ reactions using the adapter-specific primer (5'-GATGAGTCCTGAGTAA-3'). Polymerase chain reaction (PCR) conditions included 20 cycles of denaturation $\left(94^{\circ} \mathrm{C}, 30 \mathrm{~s}\right)$, annealing $\left(55^{\circ} \mathrm{C}, 1\right.$ $\mathrm{min})$, and extension $\left(72^{\circ} \mathrm{C}, 1 \mathrm{~min}\right)$. After the PCR products were purified with DNAmate (TaKaRa, Japan), they were hybridized to a biotin-labeled (GT) ${ }_{13}$ probe through denaturation at $94^{\circ} \mathrm{C}$ for $5 \mathrm{~min}$, then at $53^{\circ} \mathrm{C}$ for $15 \mathrm{~min}$.

Single-stranded DNA fragments containing microsatellite repeat sequences were captured using streptavidin-coated magnetic beads (Promega, USA). The captured DNA was eluted from the magnetic beads and amplified using the adaptor-specific primer and the above program. PCR products ranging from 500 to $1000 \mathrm{bp}$ were selected through separation on $1.5 \%$ agarose gels. The fragments were cloned into pMD18-T vectors (TaKaRa) and then transformed into Escherichia coli $\mathrm{DH} 5 \alpha$ competent cells to produce a microsatellite-enriched library. Positive clones were sequenced on an ABI 3730 automated DNA sequencer (Applied Biosystems, USA).

PCR primer pairs were designed in DNA sequence-containing microsatellite repeats using the PRIMER PREMIER 5 software (Premier Biosoft International, USA) and then tested for polymorphism from 6 S. hasta. After preliminary screening, only 17 polymorphic microsatellite loci were evaluated in a sample of 48 individuals. PCR was performed on a Veriti Thermal Cycler in a total volume of $25 \mu \mathrm{L}$ containing $0.4 \mu \mathrm{M}$ of each primer, $0.2 \mathrm{mM}$ of each deoxyribonucleotide triphosphate, 1 X PCR buffer, $2 \mathrm{mM} \mathrm{MgCl}{ }_{2}, 1 \mathrm{U}$ Taq polymerase (Fermentas, USA), and 10-100 ng DNA. Cycling conditions consisted of initial denaturation 
at $94^{\circ} \mathrm{C}$ for $5 \mathrm{~min}, 35$ cycles of $45 \mathrm{~s}$ at $94^{\circ} \mathrm{C}, 1 \mathrm{~min}$ at the locus-specific annealing temperature (Table 1), $45 \mathrm{~s}$ at $72^{\circ} \mathrm{C}$, and a final cycle of $10 \mathrm{~min}$ at $72^{\circ} \mathrm{C}$. Allele size was estimated according to the pBR322 DNA/MspI marker (TianGen, China) after PCR products were separated on $6 \%$ denaturing polyacrylamide gel. The expected and observed heterozygosities together with an analysis of Hardy-Weinberg equilibrium (HWE) and linkage disequilibrium were calculated using GENEPOP 4.0 (Raymond and Rousset, 1995). Null allele frequencies were calculated with MICRO-CHECKER 2.2.3 (Van Oosterhout et al., 2004). The significant values for all multiple tests were corrected by the sequential Bonferroni's procedure (Rice, 1989).

\begin{tabular}{|c|c|c|c|c|c|c|c|c|c|c|}
\hline Locus & Primer sequence (5'-3') & Repeat motif & $\operatorname{Ta}\left({ }^{\circ} \mathrm{C}\right)$ & $\begin{array}{l}\text { Allele size } \\
\text { range (bp) }\end{array}$ & $N_{\mathrm{A}}$ & $H_{\mathrm{o}}$ & $H_{\mathrm{E}}$ & $\mathrm{N}$ & $\mathrm{P}_{\text {HWE }}$ & $\begin{array}{l}\text { Accession } \\
\text { No. }\end{array}$ \\
\hline$\overline{\mathrm{Syn} 2^{2^{* *}}}$ & $\begin{array}{l}\text { F: CCCCACCAAATGAAAGAA } \\
\text { R: AGCGCAGCATGTAAACAA }\end{array}$ & $(\mathrm{CAA})_{6}$ & 45 & $300-310$ & 6 & 0.522 & 0.758 & 46 & 0.0002 & JQ398712 \\
\hline Syn6 & $\begin{array}{l}\text { F: CGTTCAGTGGAGGTGTAGT } \\
\text { R: CAAATTATCATCCTGGGTC }\end{array}$ & $(\mathrm{GT})_{10}$ & 57 & $255-265$ & 7 & 1.000 & 0.791 & 46 & 1.000 & JQ398713 \\
\hline Syn1 $13^{\dagger *}$ & $\begin{array}{l}\text { F:AGAGCAAACTGACAAAACC } \\
\text { R: CAGGGACAAAAGTACAAGG }\end{array}$ & $(\mathrm{CA})_{18}$ & 55 & $215-225$ & 6 & 0.422 & 0.649 & 45 & 0.000 & JQ398714 \\
\hline Syn15 & $\begin{array}{l}\text { F: ACCACTAATACCTTCCCCAAAC } \\
\text { R: GTAGCCCCGAGGAACAGC }\end{array}$ & $(\mathrm{AC})_{15}$ & 57 & $200-250$ & 9 & 0.700 & 0.798 & 40 & 0.0084 & JQ398715 \\
\hline Syn23 & $\begin{array}{l}\text { F: AACGGCTGACTGAAGAAG } \\
\text { R: CGTACTAACCATAGCTGGAA }\end{array}$ & $(\mathrm{TG})_{5}(\mathrm{GT})_{12}$ & 57 & $252-300$ & 17 & 0.792 & 0.833 & 48 & 0.0061 & JQ398716 \\
\hline Syn24 & $\begin{array}{l}\text { F: TTTTACCCGTGGATAAGTG } \\
\text { R: TTGAACGCAGCAAACATA }\end{array}$ & $(\mathrm{CTT})_{7}$ & 55 & $290-295$ & 4 & 0.708 & 0.687 & 48 & 0.5986 & JQ398717 \\
\hline $\operatorname{Syn} 26^{\dagger *}$ & $\begin{array}{l}\text { F: TGGATCTGTCACCGAAAT } \\
\text { R: GTTGATACCTGGAAGAAGAGC }\end{array}$ & $(\mathrm{AC})_{19}$ & 55 & $335-385$ & 15 & 0.729 & 0.909 & 48 & 0.000 & JQ398718 \\
\hline Syn28 & $\begin{array}{l}\text { F: CACCTGACCTTGACCCTT } \\
\text { R: TGCCTGCGTGTAGTCTATT }\end{array}$ & $(\mathrm{AC})_{9}(\mathrm{CA})_{7}(\mathrm{CA})_{5} \ldots(\mathrm{CA})_{12}$ & 55 & $240-300$ & 17 & 1.000 & 0.891 & 44 & 1.000 & JQ398719 \\
\hline Syn34 & $\begin{array}{l}\text { F: CCATTGAACTGCGTGACTA } \\
\text { R: TGAAGACTGGCATCTCCTT }\end{array}$ & $(\mathrm{TG})_{14}$ & 50 & $240-270$ & 11 & 0.917 & 0.799 & 48 & 0.9923 & JQ398720 \\
\hline Syn35 & $\begin{array}{l}\text { F: TTGTTTTGTTATTGGAGC } \\
\text { R: TGTTTGGTTGTAGTTGTATT }\end{array}$ & $(\mathrm{TG})_{14} \ldots(\mathrm{GT})_{20}$ & 50 & $180-250$ & 23 & 1.000 & 0.939 & 47 & 1.000 & JQ398721 \\
\hline Syn36 & $\begin{array}{l}\text { F: GGCTGTCCTGTGGATTGT } \\
\text { R: CGCAGATGTAAGCGAAAC }\end{array}$ & $(\mathrm{GT})_{14}$ & 50 & $180-200$ & 12 & 0.957 & 0.823 & 47 & 0.8770 & JQ398722 \\
\hline Syn37 & $\begin{array}{l}\text { F: GTGGCAGTTCCTTATTGTG } \\
\text { R:AGGCGTTGTGAGTTTCAG }\end{array}$ & $(\mathrm{GT})_{9} \mathrm{GA}(\mathrm{GT})_{5} \ldots(\mathrm{GT})_{12}$ & 55 & $260-315$ & 15 & 1.000 & 0.898 & 48 & 1.000 & JQ398723 \\
\hline Syn41 & $\begin{array}{l}\text { F: GCTGTTGTACGGATGGGAATT } \\
\text { R: TGCCGCCTCAACCTCTTT }\end{array}$ & $(\mathrm{AC})_{11} . .(\mathrm{AC})_{5 \cdot} .(\mathrm{AC})_{19}$ & 55 & $340-440$ & 15 & 0.809 & 0.851 & 47 & 0.0608 & JQ398724 \\
\hline Syn51 & $\begin{array}{l}\text { F: TCCGACACCAACAAACTCC } \\
\text { R: TTCCACCAACCGTATCTCC }\end{array}$ & $(\mathrm{AC})_{23}$ & 52 & $220-265$ & 12 & 0.938 & 0.797 & 48 & 0.9739 & JQ398725 \\
\hline Syn53 & $\begin{array}{l}\text { F: TACATTAGAGCCCTCTGCA } \\
\text { R: TCATCACCAAAACCAACC }\end{array}$ & $(\mathrm{CA})_{8}$ & 58 & $180-200$ & 10 & 0.841 & 0.816 & 44 & 0.3956 & JQ398726 \\
\hline Syn61 & $\begin{array}{l}\text { F: GAGGTCGTTCCACTTGTC } \\
\text { R: GCTGAGTTTAGGGTTTATGT }\end{array}$ & $(\mathrm{AC})_{10} . .(\mathrm{CT})_{8} \ldots(\mathrm{CA})_{9}$ & 57 & $205-210$ & 2 & 0.130 & 0.123 & 46 & 1.000 & JQ398727 \\
\hline Syn68 & $\begin{array}{l}\text { F: AAACATCAGCTCCAGAACA } \\
\text { R: GAATATGGCAAAAGACAAAA }\end{array}$ & $(\mathrm{TG})_{5 .} .(\mathrm{GT})_{20} . .(\mathrm{TG})_{13}$ & 55 & $185-240$ & 11 & 0.417 & 0.750 & 47 & 0.004 & JQ398711 \\
\hline
\end{tabular}

Ta $=$ optimized annealing temperature; $N_{\mathrm{A}}=$ number of alleles; $H_{\mathrm{O}}=$ observed heterozygosity; $H_{\mathrm{E}}=$ expected heterozygosity; $\mathrm{N}=$ number of individuals genotyped; $\mathrm{P}_{\mathrm{HWE}}=$ Hardy-Weinberg probability; $†$ Locus deviated from Hardy-Weinberg equilibrium (adjusted P value $<0.00294$ ); * Locus may harbor null alleles (null allele frequency $>5 \%$ ).

\section{RESULTS AND DISCUSSION}

The 17 loci that were successfully amplified in this study showed polymorphism, and the number of alleles per locus ranged from 2 to 23 , with an average of 11.3. The observed and expected heterozygosities ranged from 0.130 to 1.000 and from 0.123 to 0.939 , with an average of 0.758 and 0.774 , respectively (see Table 1 ). Three loci departed significantly from HWE 
$(\mathrm{P}<0.05)$ after sequential Bonferroni's correction (adjusted $\mathrm{P}$ value $<0.00294)$. The observed departure from HWE is likely due to the presence evidence of "null" alleles (syn2, syn13, and syn26). No significant linkage disequilibrium was found between any pair of loci after Bonferroni's correction. These developed loci are highly polymorphic and powerful enough to assess the population genetic structure and analyze the kinship analysis of $S$. hasta and related species.

\section{ACKNOWLEDGMENTS}

Research supported by the National Natural Science Foundation of China (\#31061160187) and the Special Fund for Marine Scientific Research in the Public Interest (\#201005013).

\section{REFERENCES}

Chen D (1978). Initial investigates of S. ommaturus in fishery harbor. Chin. J. Zool. 1: 12-15.

Feng GP, Zhang LZ, Zhuang P, Chen J, et al. (2010). Morphological character, individual fecundity and ovary histology of Acanthogobius ommaturus in Yangtze River estuary. J. Mar. Fish. 32: 257-263.

Feng J, Zu JQ, Zheng ZM and Chen YC (2004). Study on the individual fecundity of Synechogobius hasta. J. Zhejiang Ocean Univ. 23: 302-314.

Litt M and Luty JA (1989). A hypervariable microsatellite revealed by in vitro amplification of a dinucleotide repeat within the cardiac muscle actin gene. Am. J. Hum. Genet. 44: 397-401.

Luo Z, Li XD, Bai HJ, Yuan YC, et al. (2008). Comparison on nutrient composition and morphology between wild and cultured Synechogobius hasta. J. Shanghai Fish. Univ. 17: 182-186.

Ma HY and Chen SL (2009). Isolation and characterization of 31 polymorphic microsatellite markers in barfin flounder (Verasper moseri) and the cross-species amplification in spotted halibut (Verasper variegatus). Conserv. Genet. 10: 1591-1595.

Raymond $\mathrm{M}$ and Rousset $\mathrm{F}$ (1995). GENEPOP (Version 1.2): population genetics software for exact tests and ecumenicism. J. Hered. 86: 248-249.

Rice WR (1989). Analyzing tables of statistical tests. Evolution 43: 223-225.

Sambrook J and Russell DW (2001). Molecular Cloning. 3rd edn. Cold Spring Harbor, New York.

Shao CW, Liao XL, Tian YS and Chen SL (2009). Microsatellite marker analysis of genetic structures of three populations of cultured Japanese flounder Paralichthys olivaceus. Prog. Fish. Sci. 30: 41-46.

Sun GY and Chen JG (1993). Study on the biology of Synechogobius ommatrurus. J. Fish. China 17: 146-153.

Van Oosterhout C, Hutchinson WF, Wills DPM and Shipley P (2004). MICRO-CHECKER: software for identifying and correcting genotyping errors in microsatellite data. Mol. Ecol. Notes 4: 535-538.

Wang JX and Zhao XF (1994). Chromosome Study of Synechogobius ommatrurus (Osteichthyes: Gobiidae). Ocean Sci. 4: 47-50.

Yang Z, Shi F, Que YF, Xiong MH, et al. (2010). Preliminary studies on genetic diversity of first filial generation of Myxocyprinus asiaticus from artificial propagation releasing in Yangtze River. J. Hydroecol. 3: 17-20. 